\title{
SISTEM PERBANKAN DALAM NEGARA KESEJATERAAN DI INDONESIA
}

\author{
Oleh: Hendri Jayadi \\ Lonna Yohanes Lengkong \\ hendrijayadi79@gmail.com \\ Universitas Kristen Indonesia, Jakarta, Indonesia
}

\begin{abstract}
The banking system in Indonesia is regulated in Law No.7 of 1992 (amended by Law No.10 of 1998). The development of banking shows the dynamics in economic life. The banking sector in the life of a country is an agent of development, because banks are nancial institutions that have the function as nancial intermediary institutions, namely as institutions that collect funds from the public in the form of deposits and channel them back to the public in the form of credit or nancing. Banking is also an agent of trust, bearing in mind that there is one principle of bank management, the duciary principle. The provisions of Article 4 of Act Number 7 of 1992 concerning Banking as amended by Act Number 10 of 1998 states that Indonesian banks aim to support the implementation of national development in order to improve equity, economic growth, and national stability towards improving the welfare of the people at large.
\end{abstract}

Keyword:banking system; development; economic growth.

\section{Pendahuluan}

Perkembangan sistem perbankan Indonesia telah berevolusi dalam beberapa tahap yakni pada tahun 1967-1973 tahap rehabilitasi dan perbaikan dari inflasi tinggi. Pada tahun 1974-1983 adalah tahap pemberlakuan pagu aktiva netto. Pada tahun 19831988 adalah tahap pertumbuhan. Pada tahun 19881991 adalah tahap deregulasi dan tahap percepatan, serta pada tahun 1991-1997 adalah tahap konsolidasi yakni masa prinsip-prinsip kehati-hatian yang sedang diperkenalkan termasuk kecukupan modal dan peringkat Bank. ${ }^{1}$

Sistem Perbankan di Indonesia diatur dalam UU No.7 Tahun 1992 (diubah dengan UU No.10 Tahun 1998). Perkembangan perbankan menunjukkan dinamika dalam kehidupan ekonomi. Sebelum sampai pada praktik-praktik yang terjadi saat ini, adabanyak permasalahan yang terkait dengan masalah-masalah perbankan ini.

Masalah utama yang muncul dalam praktik perbankan ini adalah pengaturan sistem keuangan yang berkaitan dengan mekanisme penentuan volume

1S. Batunanggar, Indonesia's Banking Crisis Resolution: Lesson and the Way Forward, Occasional Internal Paper, Desember 2002, hlm. 4. uang yang beredar dalam perekonomian. Sistem keuangan, yang terdiri dari otoritas keuangan (financial authorities), sistem perbankan dan sistem lembaga keuangan bukan bank, pada dasarnya merupakan tatanan dalam perekonomian suatu Negara yang memiliki peran utama dalam menyediakan fasilitas jasa-jasa keuangan.

Fasilitas jasa tersebut diberikan oleh lembagalembaga keuangan, termasuk pasar uang dan pasar modal.

Pada Tahun 2018 Perbankan tanah Air sedang dihadapkan pada berbagai masalah. Salah satunya, kenaikan 7-Day Reverse Repo Rate (7-DRRR). Pada Mei-Juni lalu, Bank Indonesia (BI) sudahmenaikkan suku bunga acuan ini sebanyak 75 basis points (bps). Banyak kalangan menilai perbankan kurang optimal dalam menjalankan fungsi intermediasinya, hal tersebut berdasarkan penilaian dari berbagai pihak bahwa perbankan menerapkan strategi suku bunga yang tinggi untuk dapat mempertahankan tingkat keuntungan.

Kenaikan bunga acuan ini akan memengaruhi bisnis perbankan. 7-DRR akan berpengaruh pada pertumbuhan ekonomi. Padahal pertumbuhan ekonomi 
sangat mempengaruhi permintaan kredit. Kenaikan 7-DRR mendorong bank menaikkan bunga deposito dan bunga kredit.

Ketika pertumbuhan ekonomi lemah maka permintaan kredit akan melemah. Kenaikan bunga kredit juga akan membuat bank menghadapi kenaikan rasio kredit bermasalah atau non performing loan (NPL). ${ }^{2}$

Selain itu kuatnya tekanan terhadap rupiah mengakibatkan ketidakmampuan Bank Indonesia untuk menyangga pita intervensi (band intervention) yang ada sehingga sistem nilai tukar mengambang bebas (Free floating system) menjadi salah satu alternatif sistem nilai tukar yang akhirnya dipilih untuk tetap menjaga cadangan devisa. Disamping sebagai dampak dari bergejolaknya nilai rupiah, sektor perbankan mengalami krisis yang sangat mendalam karena menurunnya kepercayaan masyarakat terhadap sistem perbankan. Hal tersebut semakin diperberat oleh lemahnya kondisi internal sektor perbankan, terutama sebagai dampak dari konsentrasi kredit yang berlebihan, lemahnya manajemen bank, moral hazard yang timbul akibat mekanisme exit yang belum tegas serta belum efektifnya peagawasan yang dilakukan oleh Bank Indonesia. Secara keseluruhan, akibat dari krisis yang semakin mendalam telah memperburuk tidak saja aspek likuiditas perbankan, tetapi juga aspek solvabilitas dan rentabilitasnya mengingat perbankan merupakan market dominan dalam industrikeuangan di Indonesia, maka secara sistematis sektor Keuangan juga mengalami kelumpuhan. Dampak negatif krisis pada perekonomian di negara ini secara keseluruhan akibat hilangnya pertumbuhan ekonomi, investasi , meningkatnya pengangguran, social cost lainnya akibat terjadinya instabilitas sosial politik sebagai dampak ikutan di saat krisis terjadi. ${ }^{3}$

\section{Permasalahan}

Bagaimana Sistem Perbankan dalam Negara Kesejateraan di Indonesia?

\footnotetext{
2https://www.cnbcindonesia.com/market/20180709142737-1722642/masalah-terbaru-perbankan-saat-ini-pengelolaan-likuiditas

3http://www.lfip.org/english/pdf/bali-seminar/Masalah\%20sistem\%20keuangan\%20dan\%20perbankan\%20-\%20anwar\%20 nasution.pdf
}

\section{Tujuan Penulisan}

Untuk Mengetahui Sistem Perbankan Dalam Negara Kesejahteraan Di Indonesia.

\section{Sistem Perbankan dalam Negara Kesejateraan}

Perbankan adalah segala sesuatu yang menyangkut tentang bank,mencakup kelembagaan, kegiatan usaha, serta cara dan prosesdalam melaksanakan kegiatan usahanya; ${ }^{4}$

Bank adalah badan usaha yang menghimpun dana dari masyarakat dalam bentuk simpanan dan menyalurkannya kepadamasyarakat dalam bentuk kredit dan atau bentuk-bentuk lainnyadalam rangka meningkatkan taraf hidup rakyat banyak; ${ }^{5}$

- Peranan Bank Dalam Perekonomian

- Alokasi Dana (Fungsi Intermediasi).

- Layanan Lalu Lintas Pembayaran.

- Transmisi Kebijakan Moneter

- Sistem Perbankan di Indonesia

Sistem Perbankan di Indonesia diatur dalam UU Nomor 7 Tahun 1992 (diubah dengan UU No.10 Tahun 1998) tentang Perbankan.

Perbankan di Indonesia dapat dikelompokkan menurut jenis, Bank Umum (BU) dan Bank Perkreditan Rakyat (BPR)

- Menurut Kepemilikan

- Bank Milik Pemerintah (Bank Pesero)

- BPD (milik pemerintah Daerah)

- Bank Swasta Nasional

- Bank Asing

- Menurut Ruang Lingkup Kegiatan adan Bank

Devisa dan Bank Nondevisa

\section{Bank Indonesia}

Bank Indonesia memiliki peranan lain selain sebagai bank sentral yang memiliki kewenangan sebagai regulator, antara lain: ${ }^{6}$

\footnotetext{
$\overline{4 P a s a l} 1$ Ayat (1) Undang-Undang Republik Indonesia Nomor 10 Tahun 1998 Tentang Perbankan.

5 Pasal 1 Ayat (2) Undang-Undang Republik Indonesia Nomor 10 Tahun 1998 Tentang Perbankan.

6 Julius R. Latumaerissa, Bank \& Lembaga Keuangan Lain Teori dan Kebijakan, Jakarta: Mitra Wacanaa Media, 2017
} 
- Peran Bank Indonesia Sebagai Lender of The Last Resort.

- Kebijakan Nilai Tukar. Kewenangan Bank Indonesia dalam melaksanakan kebijakan nilai tukar ini antara lain dapat berupa:

- Dalam sistem nilai tukat tetap berupaya devaluasi atau revaluasi terhadap mata uang asing;

- Dalam sistem nilai tukar mengambang berupa intervensi pasar;

- Dalam nilai tukar mengambang terkendali berupa penetapan nilai tukar harian serta lebar pita intervensi.

- Kewenangan dalam Mengelola Cadangan Devisa.

- Penyelenggaraan Survei.

Bank Indonesia sendiri, yang pada hakekatnya menurut esensi Undang-Undang Nomor 23 Tahun 1999 tentang Bank Indonesia meliputi : ${ }^{7}$

- Secara yuridis UU BImerupakan landasan yuridis bagi independensi Bank Indonesia dimana dalam UU BI dimuat elemen-elemen seperti status dan kedudukan, tujuan dan tugas serta manajemen dan personalia dari independensi Bank Indonesia;

- Secara personalia independensi personalia dalam UU BI ditunjukan dalam hal pengangkatan anggota Dewan Gubernur oleh Presiden dengan persetujuan DPR.

- Secara struktural, istitusi Bank Indonesia berada di luar pemerintah sehingga dalam melaksanakan tugas dan fungsinya bebas dari campur tangan pemerintah atau pihak-pihak lainnya.

- Tujuan dalam UU BI adalah Bank Indonesia difokuskan pada menjaga kestabilan nilai rupiah yang tercermin pada laju inflasi yang rendah dan kestabilan nilai tukar.

- Tugas yang dilaksanakan harus independen dalam pelaksanaan tugas tercermin dari larangan bagi pihak lain untuk melakukan segala bentuk campur tangan terhadap pelaksanaan tugas Bank Indonesia.

- Manajemen Bank Indonesia yaitu Dewan Gubernur yang sepenuhnya berwenang dalam menjalankan organisasi Bank Indonesia dalam rangka mencapai tujuan yang telah ditetapkan oleh UU BI.

- Independen dalam bidang anggaran terlihat dalam ketentuan Pasal 600 UU BI yang menyatakan bahwa anggaran Bank Indonesia ditetapkan oleh Dewan Gubernur.

- Transparansi dalam melaksanakan tugas Bank Indonesia dituntut untuk lebih transparan dan bertanggung jawab yang diwujudkan dengan pertanggungjawaban kepada publik.

Akuntabilitas yaitu dalam UU BI dianut pertanggungjawaban publik, dimana pada setiap awal tahun anggaran Bank Indonesia wajib menyampaikan informasi kepada masyarakat secara terbuka melalui media massa mengenai evaluasi pelaksanaan kebijakan moneter tahun sebelumnya dan rencana kebijakan moneter tahun yang akan datang. Informasi tersebut juga disampaikan kepada Presiden dan DPR.

\section{Teori Negara Kesejahteraan}

Perkembangan pemikiran mengenai negara hukum, dikenal dua kelompok negara hukum, yakni negara hukum formal dan negara hukum materiil. Negara hukum materiil ini dikenal juga dalam istilah welfarestate atau negara kesejahteraan. Negara Kesatuan Republik Indonesia juga menganut faham negara kesejahteraan sebagaimana diatur dalam Pasal 33 Undang-Undang Dasar Negara Republik Indonesia Tahun 1945 beserta dengan perubahannya(UUD 1945). UUD 1945 merupakan landasan struktural yang dijadikan konstitusi Negara Republik Indonesia. Dasar keberadaan konstitusi adalah kesepakatan umum atau persetujuan (consensus) di antara mayoritas rakyat mengenai bangunan yang diidealkan berkenaan dengan negara.

Organisasi negara itu diperlukan oleh warga masyarakat politik agar kepentingan mereka bersama dapat dilindungi atau dipromosikan melalui pembentukan dan penggunaan mekanisme yang disebut negara. ${ }^{8}$

Para Perintis Kemerdekaan dan para Pendiri Negara Kesatuan Republik Indonesia 8Jimlly Asshiddiqie, Konstitusi dan Hak Asasi Manusia, Jakarta: disampaikan pada Lecture Peringatan 10 Tahun 
menegaskan bahwa negara demokratis yang akan didirikan adalah "Negara Kesejahteraan" (walvaarstaat) bukan "Negara Penjaga Malam" (nachtwachterstaat). Teori welfare state secara maknawi adalah Negara Kesejahteraan yang dijadikan sebagai grand theory analisis, hal ini sesuai dengan problematika yuridis yang berkorelasi dengan pengembangan konsep serta seputar diskursus tentang hukum kebijakan pelayanan publik. $^{9}$

Konsep Negara hukum kesejahteraan atau welfare state pada dasarnya muncul sebagai antitesa terhadap tipe Negara hukum sebelumnya, yaitu konsep Negara "penjaga malam" atau "nachwachterstaat." Perkembangan Negara sebagai "penjaga malam", muncul gejala kapitalisme di ranah perekonomian yang secara perlahan-lahan menyebabkan terjadinya kepincangan dalam pembagian sumber-sumber kemakmuran bersama.

Kemiskinan yang timbul menjadi jurang yang kian menunjukkan kecenderungan yang semakin menajam, yang sulit dipecahkan oleh Negara yang difungsikan secara minimal, kenyataan ini kemudian mendorong munculnya sebuah kesadaran baru mengenai pentingnya adanya keterlibatan Negara dalam menangani dan mengatasi masalah ketimpangan tersebut. Negara dianggap tidak dapat melepaskan tanggungjawabnya untuk meningkatkan kesejahteraan masyarakat, oleh karena itu, Negara perlu turut campur dalam mengatur sumber-sumber kemakmuran agar tidak dikuasai oleh segelintir orang. ${ }^{10}$

Negara yang sedang berkembang tujuan utamanya adalah mewujudkan kesejahteraan masyarakat yang merata. Negara yang demikian ini disebut Negara yang bertipe kesejahteraan (welfare state type), karena titik beratnya adalah pemerataan kesejahteraan dalam kehidupan masyarakat, maka Negara dituntut untuk berperan aktif dalam menciptakan kesejahteraan ini. Kesejahteraan tersebut untuk mewujudkannya tidak dapat diserahkan sepenuhnya kepada masyarakat,

9Mustafa Luthfi dan J. Kurniawan, Perihal Negara, Hukum dan Kebijakan Publik : Perspektif Politik Kesejahteraan, Kearifan Lokal yang Pro Civil Society dan Gender, Malang: Setara Press, 2012, hlm.48

$10 \mathrm{Ibid}, \mathrm{hlm} .50$ sebab apabila hal tersebut dilakukan, maka yang terjadi bukan kesejahteraan yang merata, melainkan timbulnya persaingan yang bebas yang dijiwai oleh semangat free fight liberalism. ${ }^{11}$

Menurut Ridwan HR, konsepsi Negara hukum modern merupakan perpaduan antara konsep Negara hukum dan Negara kesejahteraan. Konsep ini Negara atau pemerintah tidak semata-mata sebagai penjaga ketertiban atau keamanan masyarakat saja, tetapi juga memikul tanggungjawab dalam mewujudkan keadilan sosial, kesejahteraan umum dan sebesar-besarnya untuk kemakmuran rakyat. ${ }^{12}$

Menurut Moh. Koesnoe, sejak Negara Indonesia diproklamirkan, bangsa Indonesia meneguhkan janji untuk mewujudkan cita-cita bangsa, yaitu mewujudkan kesejahteraan sosial bagi seluruh rakyat Indonesia. Cita-cita tersebut dirumuskan dalam Pembukaan Undang-Undang Dasar Negara Republik Indonesia Tahun 1945, tepatnya dalam alinea keempat yang menyatakan bahwa tujuan membentuk suatu pemerintah Negara Indonesia adalah untuk memajukan kesejahteraan umum, mencerdaskan kehidupan bangsa dan ikut melaksanakan ketertiban dunia yang berdasarkan kemerdekaan, perdamaian abadi dan keadilan sosial. ${ }^{13}$

Negara kesejahteraan merupakan bagian dari sebuah masyarakat modern yang sejalan dengan ekonomi pasar kapitalis dan struktur politik demokratis. Konsep ini dipandang sebagai bentuk keterlibatan Negara dalam memajukan kesejahteraan rakyat setelah mencuatnya bukti-bukti empirik mengenai kegagalan pasar (market failure) pada masyarakat kapitalis dan kegagalan Negara (state failure) pada masyarakat sosialis. Negara kesejahteraan merupakan jalan tengah dari ideologi kapitalisme dan sosialisme. ${ }^{14}$

Negara yang menganut konsep Negara kesejahteraan dapat mengemban empat fungsi, yakni sebagai berikut :

\footnotetext{
11Muchsan, Sistem Pengawasan Terhadap Perbuatan Aparat Pemerintah dan Peradilan Tata Usaha Negara, Yogyakarta: Liberty, 2007, hlm.7.

12Ridwan HR, Hukum Administrasi Negara, Yogyakarta: UII Press, 2003, hlm.11.

13Adriani Nurdin, Kepailitan BUMN Persero Berdasarkan Asas Kepastian Hukum, Jakarta: Alumni, 2012, hlm. 25.
}

14 Ibid, hlm.27. 
- The State as Provider (Negara sebagai pelayan),

- The State as Regulator (Negara sebagai pengatur),

- The State as Enterpreneur (Negara sebagai wirausaha),

- The State as Umpire (Negara sebagai wasit). ${ }^{15}$

Berdasarkan empat fungsi tersebut, pemerintah dalam Negara kesejahteraan diberi tugas membangun kesejahteraan umum dalam berbagai bidang. ${ }^{16}$ Pemerintah tidak boleh pasif atau berlaku sebagai "penjaga malam", melainkan harus aktif melaksanakan upaya-upaya untuk membangun kesejahteraan masyarakat dengan cara membangun kehidupan ekonomi dan sosial masyarakat. Tugas Negara tidak terbatas pada memelihara tata-tertib serta melindungi jiwa dan harta kekayaan rakyatnya (police state), melainkan juga Negara bertugas mewakili kepentingan bersama, meningkatkan kemakmuran yang adil dan merata (welfarestate), atau dalam melaksanakan tugasnya Negara mempunyai kewajiban memperhatikan kepentingan bersama. ${ }^{17}$

Negara kesejahteraan adalah sebuah sistem kesejahteraan sosial yang dapat memberi peran lebih besar pada Negara atau pemerintah (untuk mengalokasikan sebagian dana publik demi menjamin terpenuhinya kebutuhan dasar warganya). Negara hukum kesejahteraan merupakan bentuk perlindungan Negara terhadap masyarakat terutama kelompok lemah seperti orang miskin, cacat, pengangguran dan sebagainya. ${ }^{18}$

Menurut Jimly Asshiddiqie, sejalan dengan pendapat para pakar di atas, menyatakan bahwa dalam konsep Negara kesejahteraan, Negara dituntut untuk memperluas tanggungjawabnya kepada masalahmasalah sosial ekonomi yang dihadapi oleh rakyat banyak. Perkembangan inilah yang memberikan legalisasi bagi penganut Negara intervensionis pada abad ke-20. Negara justru perlu dan bahkan harus melakukan intervensi dalam berbagai masalah sosial

15 I bid, hlm.27.

16Astim Riyanto, Teori Konstitusi, Bandung: Yapemdo, 2000, hlm.280.

17 Adriani Nurdin, Op.Cit, hlm.28.

18 Mustafa Luthfi dan J. Kurniawan, Op.Cit, hlm.51. Lihat juga : E. Suharto, Analisa Kebijakan Publik, Bandung: Alfabeta, 2006, hlm.50. dan ekonomi untuk menjamin terciptanya kesejahteraan bersama dalam kehidupan masyarakat. ${ }^{19}$

Pemerintah melakukan campur tangan dengan tujuan tidak lain untuk mewujudkan kesejahteraan yang merata dalam kehidupan masyarakat agar masyarakat adil dan makmur dalam segala aspeknya, sedangkan sasarannya adalah pola perilaku masyarakat. Masyarakat akan direkayasa agar berperilaku sesuai dengan derap pembangunan yang dilaksanakan oleh Negara, dengan demikian pola perilaku tersebut dapat menunjang arah pembangunan, yang tendensinya dapat mempercepat terwujudnya tujuan pembangunan. ${ }^{20}$

Campur tangan Negara dalam Negara hukum Indonesia harus diatur sebelumnya dalam peraturan-peraturan hukum. Peraturan hukum tersebut berfungsi sebagai acuan dalam mengarahkan perubahan pola perilaku masyarakat yang bersangkutan. Hukum disini harus berfungsi sebagai alat untuk merekayasa kehidupan masyarakat (as a tool of social engineering). ${ }^{21}$

Moh. Hatta menggunakan istilah "Negara Pengurus" terhadap konsepsi negara kesejahteraan Indonesia. ${ }^{22}$ Prinsip welfarestate dalam UUD 1945 dapat ditemukan rinciannya dalam beberapa pasal, terutama yang berkaitan dengan aspek sosial ekonomi.

Konsep kesejahteraan dalam UUD 1945, menurut Jimly Asshidiqie Konstitusi Indonesia dapat disebut sebagai konstitusi ekonomi (economic constitution) dan bahkan konstitusi sosial (social constitution), sebagaimana juga terlihat dalam konstitusi Negara Rusia, Bulgaria, Cekoslowakia, Albania, Italia, Belarusia, Iran, Suriah dan Hongaria, selanjutnya menurut Jimly Asshidiqie, sejauh menyangkut corak muatan yang diatur dalam UUD Tahun 1945, nampak dipengaruhi oleh corak penulisan konstitusi yang

\footnotetext{
19Jimly Asshiddiqie, Gagasan Kedaulatan Rakyat dalam Konstitusi dan Pelaksanaannya di Indonesia, Jakarta: Ichtiar Baru Van Hoeve, 1994, hlm. 223.

20 Muchsan, Op.Cit, hlm.10.

$21 \mathrm{Ibid}$, hlm.10.

22 M. Yamin, Naskah Persiapan UUD 1945: Risalah Sidang BPUPKI/PPKI, Jakarta: Sekretariat Negara RI, 1959, hlm. 299.
} 
lazim ditemui pada Negara-negara sosialis. ${ }^{23}$

Negara telah ikut campur dalam perekonomian rakyat melalui politik hukum sejak masuknya paham welfare state. Politik hukum secara sederhana dapat dirumuskan sebagai kebijakan hukum (legal policy) yang akan atau telah dilaksanakan secara nasional oleh pemerintah, mencakup pula pengertian tentang bagaimana politik memengaruhi hukum dengan cara melihat konfigurasi kekuatan yang ada dibelakang pembuatan dan penegakan hukum tersebut. ${ }^{24}$ Kebijakan disepadankan dengan kata bahsa Inggris yaitu policy yang berbeda dengan kata wisdom yang berarti kebijaksanaan atau kearifan. Istilah policy (kebijakan) sering penggunaannya saling dipertukarkan dengan istilah lain seperti tujuan, program, keputusan, undang-undang, ketentuanketentuan, usulan-usulan, dan rancanganrancangan besar. Menurut Perserikatan BangsaBangsa, kebijakan diartikan sebagai pedoman untuk bertindak. Pedoman itu boleh jadi amat sederhana atau amat kompleks, bersifat umum atau khusus, luar atau sempet, kabur atau jelas, longgar atau terperinci berifat kualitatif atau kuwantitatif, public atau privat. Kebijakan dalam makna seperti ini dapat disimpulkan sebagai suatu deklarasi mengenai suatu dasar pedoman bertindak, suatu arah atau tindakan tertentu, suatu program mengenai aktifitas-aktifitas tertentu atau suatu rencana ${ }^{25}$ yang terwujud dalam bentuk peraturan perundang-undangan. Landasan yuridis campur tangan Negara didasarkan pada ketentuan Pasal 33 UUD 1945 yang menganut demokrasi ekonomi, dalam demokrasi ekonomi

yang berdasarkan Pancasila dan UUD 1945 harus dihindari sistem free fight liberalism, yang menumbuhkan eksploitasi terhadap manusia dan persaingan tidak sehat serta pemusatan kekuatan ekonomi pada satu kelompok dalam berbagai bentuk monopoli dan monopsoni yang merugikan masyarakat dan bertentangan dengan cita-cita

23Jimly Asshiddiqie, Hukum Tata Negara dan Pilar-Pilar Demokrasi, Jakarta: Konstitusi Press, 2005, hlm.124.

24 M. Mahfud MD, Politik Hukum di Indonesia, Jakarta: Rajawali Press, 2009, hlm. 9.

25 Solichin Abdul Wahab, Analisis Kebijaksanaandari Formulasi ke Implementasi Kebijaksanaan Negara, Jakarta: Bumi Aksara, 2008, hlm. 2. keadilan sosial. ${ }^{26}$

Politik hukum menyerahkan otoritas legislasi kepada penyelenggara Negara dalam merumuskan dan menetapkan hukum yang telah dan akan dilakukan, tetapi dengan tetap memperhatikan nilai-nilai yang berlaku dimasyarakat. Perhatian tersebut diarahkan dalam rangka mencapai tujuan Negara yang dicita-citakan adalah memajukan kepentingan masyarakat dalam kerangka keadilan, kebebasan, dan solidaritas bangsa. ${ }^{27}$ Konsep Negara hukum dan negara kesejahteraan tugas Negara atau pemerintah, menurut Bagir Manan tidak semata-mata sebagai penjaga keamanan atau ketertiban masyarakat aja tetapi memikul tanggungjawab mewujudkan keadilan sosial, kesejahteraan umum dan untuksebesar-besarnya kemakmuran rakyat. ${ }^{28}$

Pemerintah di suatu Negara welfare state dituntut memainkan peranan yang lebih luas dan aktif, karena ruang lingkup kesejahteraan rakyat semakin meluas dan mencakup bermacam-macam segi kehidupan. Tugas pemerintah yang demikian itu sebagai bestuurzorg yang dikenal dengan service public atau penyelenggaraan kesejahteraan umum yang dilakukan oleh pemerintah. Pembuat undangundang tidak mungkin mengatur segala macam hak, kewajiban dan kepentingan secara lengkap dalam suatu undang-undang. ${ }^{29}$ Pada dasarnya harus dipahami bahwa kuasa atas Negara merupakan sebagai rumusan kehidupan keseharian dari prinsip kedaulatan rakyat yang merupakan inti dari republik. ${ }^{30}$

Negara Kesatuan Republik Indonesia, arah kebijakan hukum yang hendak dibangun dan dikembangkan selain ditujukan untuk menciptakan

\footnotetext{
26 Zulfi Diane Zaini, Independensi Bank Indonesia dan Penyelesaian Bank Bermasalah, Bandung: Keni Media, 2012, hlm.55.

27 Frans Magnis-Suseno, Etika Politik, Prinsip-prinsip Dasar Kenegaraan Modern, Jakarta: Gramedia Pustaka Utama, 1994, hlm.310-314.

28 Bagir Manan, Politik Perundang-undangan Dalam Rangka Mengantisipasi Liberalisme Perekonomian, Bandar Lampung: FH-UNILA, 1996, hlm 16.

29 Marcus Lukman, Eksistensi Peraturan Kebijaksanaan dalam Bidang Perencanaan dan Pelaksanaan Rencana Pembangunan di Daerah Serta Dampaknya Terhadap Pembangunan Materi Hukum Tertulis Nasional, Disertasi, Bandung: Universitas Padjadjaran 1997, hlm.205.

30 Sylvia Tiwon dalam Mustafa Luthfi dan J. Kurniawan, Perihal Negara, Hukum dan Kebijakan Publik: Perspektif Politik Kesejahteraan, Kearifan Lokal yang Pro Civil Society dan Gender, Malang: Setara Press, 2012, hlm. 48.
} 
sistem hukum nasional, juga yang lebih penting adalah mewujudkan kesejahteraan masyarakat. Politik hukum ada yang bersifat tetap (permanen) dan ada juga yang bersifat temporer. Politik hukum yang bersifat tetap adalah berkaitan dengan sikap hukum yang akan selalu menjadi dasar kebijakan pembentukan dan penegakan hukum.

Politik hukum yang bersifat temporer adalah kebijakan yang ditetapkan dari waktu ke waktu sesuai dengan kebutuhannya, inilah yang dimaksudkan sebagai salah satu bagian dari politik hukum yang bersifat tetap. ${ }^{31}$ Abdul Hakim Garuda Nusantara, mengatakan bahwa hukum yang hendak dibangun seyogianya harus senantiasa mengacu kepada cita-cita masyarakat Indonesia, yaitu tegaknya Negara hukum yaitu negara yang berlandaskan atas hukum dan yang menjamin keadilan bagi warganya. Kewenangan dan tindakan alat-alat perlengkapan negara atau penguasa, semata-mata berdasarkan hukum atau dengan kata lain diatur oleh hukum, sehingga akan mencerminkan keadilan bagi pergaulan hidup warganya, ${ }^{32}$ yang demokratis dan berkeadilan sosial.

Pandangan yang demikian dikatakan bahwa politik hukum Indonesia sesungguhnya harus berorientasi pada cita-cita negara hukum yang didasarkan atas prinsip-prinsip demokrasi dan berkeadilan sosial dalam suatu masyarakat Bangsa Indonesia yang bersatu sebagaimana yang tertuang dalam Pembukaan UUD 1945. ${ }^{33}$ Konsep Negara hukum kesejahteraan menjunjung tinggi adanya sistem hukum yang menjamin tentang kepastian hukum dan perlindungan terhadap hak-hakdasar rakyat, yang salah satunya adalah pelindungan hukum terhadap nasabah bank, ${ }^{34}$ sebagai upaya untuk mewujudkan kesejahteraan masyarakat sudah diamanatkan dalam UUD 1945.

\footnotetext{
31 Bagir Manan, Menyongsong Fajar Otonomi Daerah, Yogyakarta: FH UII, 2001, hlm.180.

32 Abu Daud Busroh dan Abubakar Busro, Asaz-Asaz. Hukum Tata Negara, Jakarta: Ghalia Indonesia, 1991, hlm. 110.

33 Abdul Hakim G. Nusantara, 1988, Politik Hukum Indonesia, Jakarta: YLBHI, hlm.20.

34 Mustafa Luthfi dan J. Kurniawan, Perihal Negara, Hukum dan Kebijakan Publik : Perspektif Politik Kesejahteraan, Kearifan Lokal yang Pro Civil Society dan Gender, Malang: Setara Press, 2012, hlm. 48.
}

Industri perbankan sebagai salah satu komponen dalam sistem keuangan dan sistem perekonomian memegang peranan penting dalam membangun kesejahteraan masyarakat karena peranannya yang mendominasi perekonomian nasional. Peran tersebut harus mempertimbangkan aspek stabilitas sistem keuangan agar tidak terjadi dampak yang tidak diinginkan apabila terjadi gejolak pada perekonomian atau gangguan pada sistem keuangan. Industri perbankan dapat melakukan banyak hal untuk turut memberikan kontribusi dalam pembangunan ekonomi. Kontribusi tersebut tujuannya memberikan manfaat yang sebesar-besarnya bagi peningkatan taraf hidup masyarakat serta mendukung kemandirian bangsa, maka diperlukan kebijakan dan strategi perbankan nasional yang komprehensif, terintegrasi, dan memiliki nilai tambah.

Meningkatkan kesejahteraan umum merupakan salah satu dari cita-cita nasional Indonesia, sebagaimana dirumuskan dalam Pembukaan UUD 1945, tepatnya pada alinea ke empat yang berbunyi :

"Kemudian daripada itu untuk membentuk suatu pemerintah negara Indonesia, yang melindungi segenap bangsa Indonesia dan seluruh tumpah darah Indonesia dan untuk memajukan kesejahteraan umum, mencerdaskan kehidupan bangsa, dan ikut melaksanakan ketertiban dunia yang berdasarkan kemerdekaan, perdamaian abadi dan keadilan sosial, ..."

Tujuan untuk mencapai taraf bangsa yang modern, institusi ekonomi, khususnya institusi keuangan sangat diperlukan. Fungsi dan peranan institusi ekonomi adalah untuk mengelola ketidakpastian jangka pendek maupun jangka panjang. Tujuan pembangunan institusi ekonomi dapat juga dikatakan meningkatkan stabilitas ekonomi jangka panjang. ${ }^{35}$ Perkembangan perekonomian dunia, lembaga perbankan merupakan lembaga keuangan yang paling pesat berkembang.

\footnotetext{
35 Mandala Manurung \& Prathama Rahardja, Uang, Perbankan, dan Ekonomi Moneter (Kajian Kontekstual Indonesia), Jakarta: FE-Universitas Indonesia, 2004, hlm.36.
} 
Pada Negara-negara sedang berkembang seperti Indonesia, fungsi dan peran perbankan dalam perekonomian sangat penting dan strategis. Bank umum ${ }^{36}$ sangat penting dalam hal menopang pembangunan ekonomi. Kredit-kredit dalam rangka percepatan pembangunan ekonomi, sebagian besar disalurkan oleh bank umum. Pendirian bank umum milik pemerintah juga mempunyai misi pembangunan di Indonesia. Pada tahun 1983 setelah era regulasi perbankan, pemerintah-pemerintah daerah ikut mendirikan bank yang merupakan Badan Usaha Milik Daerah (BUMD), yang juga salah satu tujuannya menopang pembangunan daerah. Kegiatan bank umum sangat luas, maka biaya ekonomi dari resiko kegagalan pengelolaan bank umum sangat besar.

Bank umum merupakan bank yang paling banyak dan luas kegiatannya, mencakup :

- Menghimpun dana dari masyarakat (funding), berupa: giro (demand deposit), tabungan (saving deposit) dan deposito berjangka (time deposit);

- Menyalurkan dana ke masyarakat (lending), dalam bentuk antara lain: kredit investasi, kredit modal kerja, dan kredit perdagangan;

- Memberikan jasa-jasa lainnya (service) seperti: transfer (kiriman uang), kliring (clearing), letter of credit $(L / C)$, menerima setoran-setoran, melayani pembayaran-pembayaran;

- Kegiatan di pasar modal: penjamin emisi (underwriter), penjamin (guarantor), wali amanat (trustee), pedagang sekuritas (dealer).

Lembaga perbankan yang memegang peranan penting dan strategis, merupakan salah satu bukti bahwa lembaga perbankan adalah salah satu pilar utama bagi pembangunan ekonomi dalam menunjang pelaksanan pembangunan nasional. ${ }^{37}$ Lembaga perbankan memiliki peran yang sangat besar dalam pencapaian keberhasilan pelaksanaan kebijaksanaan pembangunan, khususnya dalam bidang ekonomi Indonesia. ${ }^{38}$

36 Ibid, hlm. 120.

37 Zulfi Diane Zaini, Op.Cit, hlm.40-41.

$38 \mathrm{Ibid}$, hlm.7.

\section{Teori Keadilan Pancasila}

Nilai dasar hukum keadilan sosial terdapat dalam Pembukaan UUD 1945. Penjelasan UUD 1945 - sebelum perubahan - dikemukakan "Negara hendak mewujudkan keadilan sosial bagi seluruh rakyat”. Menurut Mochtar Kusumaatmaja, keadilan sosial mengamanatkan hidup bernegara harus mewujudkan keadilan dalam masyarakat, setidak-tidaknya setiap anggota masyarakat mempunyai kesempatan yang sama dalam usaha mencapai tujuan hidupnya, tanpa perbedaan berdasarkan agama, ras, atau kedudukan sosial, setiap orang sama (sederajat) dalam hukum. ${ }^{39}$ Persamaan tidak saja berarti perlakuan yang sama terhadap yang sama, namun juga perlakuan yang tidak sama dalam hal yang tidak sama (khusus). ${ }^{40}$

Konsep keadilan mendapat perhatian yang besar oleh para pendiri bangsa Indonesia, yang diantaranya ditunjukkan dengan digunakannya kata "adil" sebanyak dua kali dalam rumusan Pancasila yang merupakan Dasar Negara Republik Indonesia yaitu pada sila ke-2 yang menyatakan kemanusiaan yang adil dan beradab dan sila ke-5 yang menyatakan keadilan sosial bagi seluruh rakyat Indonesia. Pancasila menyebutkan secara tegas tentang keadilan yaitu keadilan yang beradab dan keadilan sosial. Pancasila, sebagaimana dinyatakan oleh Soekarno adalah bagian dari philosofischegrondslag dari Negara Republik Indonesia ini. Philosofische grondslag tersebut adalah "pundamen, filsafat, pikiran yang sedalam-dalamnya, jiwa, hasrat yang sedalam-dalamnya untuk di atasnya didirikan gedung Indonesia Merdeka yang kekal dan abadi”.

Pancasila adalah lima nilai luhur yang ada dan berkembang dalam bangsa Indonesia dari sejak dahulu sampai dengan sekarang, di mana nilai-nilai yang ada dalam Pancasila adalah nilai-nilai yang sesuai dan akar dalam bangsa Indonesia sendiri. Nilai-nilai tersebut merupakan nilai-nilai yang banyak digali oleh the founding fathers dalam perumusan dasar Negara yang

39 Mochtar Kusumaatmaja, "Pengembangan Filsafat Hukum Nasional”, dalam Pro Justitia Tahun XV Nomor 1 Januari 1997, hlm.8.

40 Mohammad Jamin, Soehartono, Sri Lestari Rahayu \& Mulyanto, Politik Hukum Pengakuan Kesatuan Masyarakat Hukum Adat di Indonesia, Surakarta: UNS Press, 2015, hlm.16. 
akan dipakai oleh bangsa Indonesia setelah mencapai kemerdekaannya. ${ }^{41}$

Pembukaan UUD 1945 merupakan kristalisasi seluruh sejarah pergerakan nasional bangsa Indonesia sampai titik klimaksnya yaitu Proklamasi Kemerdekaan. Proklamasi Kemerdekaan Negara Republik Indonesia yang dibangun sebagai institusi yang mampu mengantar bangsa Indonesia mencapai dan mewujudkan keinginannya secara bersama ini merupakan cerminan visi dan kesadaran, citacita moral bangsa. Pembukaan UUD 1945 harus dipahami sebagai satu keseluruhan, di mana setiap alinea mengungkapkan maknanya dalam kaitan fungsionalnya dengan alinea lain..$^{42}$

Pancasila juga sebagai suatu sistem ekomoni lazim disebut Sistem Ekonomi Pancasila. Sistem Ekonomi Pancasila mengacu pada setiap sila sebagai berikut. ${ }^{43}$

- Roda kegiatan ekonomi bangsa digerakkan oleh rangsangan-rangsangan ekonomi, sosial, dan moral;

- Seluruh warga masyarakat bertekad untuk mewujudkan kemerataan sosial yaitu tidak membiarkan berkembangnya ketimpangan ekonomi dan kesenjangan sosial;

- Semua pelaku ekonomi yaitu produsen, konsumen, dan pemerintah (sebagai produsen sekaligus konsumen) selalu bersemangat nasionalistik, yang dalam setiap putusan ekonominya menomorsatukan tujuan terwujudnya perekonomian nasional yang kuat dan tangguh;

- Koperasi dan organisasi-organisasi ekonomi yang selalu mengedepankan kerjasama (cooperation) dan tindakan bersama (collective action) menjadi sokoguru kegiatan ekonomi masyarakat;

- Dalam perekonomian Indonesia yang luas dan beragam terus menerus diupayakan keseimbangan antara perencanaan ekonomi nasional dengan desentralisasi dan otonomi daerah, melalui partisipasi aktif setiap daerah, aturan main keadilan

41 Heri Herdiawanto \& Jumanta Hamdayama, Cerdas, Kritis, dan Aktif Berwarganegara, Jakarta: Erlangga, 2010, hlm.152.

42 Pokja Ideologi Lemhannas RI, Modul Bidang Studi/Materi Pokok Pancasila dan Perkembangannya, PPRA XLVIII, TA. Lemhannas RI, 2012, hlm.. 25.

43 Mubyarto, Pemberdayaan Ekonomi Rakyat dan Peranan IlmuIlmu Sosial, Yogyakarta: BPFE, 2002, hlm. 28.. ekonomi berjalan sehingga menghasilkan keadilan sosial bagi seluruh rakyat.

Mubyarto membedakan keadilan sosial dengan keadilan ekonomi. Keadilan sosial sangat berkait dengan keadilan distribusi atau pembahagian hasil yang adil daripada produksi atau pendapatan nasional. Keadilan ekonomi adalah memberikan kesempatan yang sama pada setiap orang untuk melakukan produksi. $^{44}$

Ekonomi menurut Pancasila adalah berdasarkan asas kebersamaan, kekeluargaan yang bersendikan keadilan artinya walaupun terjadi persaingan namun tetap dalam kerangka tujuan bersama sehingga tidak terjadi persaingan bebas yang mematikan. ${ }^{45}$ Sistem Ekonomi Pancasila sangat relevan dengan kondisi sosial-ekonomi kita saat ini. Pesatnya perkembangan ilmu (ideologi) ekonomi global yang sudah semakin mengarah pada keyakinan layaknya agama, rasanya tidak sulit mengamati ekses dari kecenderungan global tersebut di Indonesia. Relevansi Ekonomi Pancasila dapat dideteksi dari cita-cita ideal pendiri bangsa, yang terangkum dalam kajian lima platform Ekonomi Pancasila yang bersifat holistik dan visio-revolusioner. ${ }^{46}$

Pemerintah Negara Indonesia mewujudkan keadilan sosial merupakan tugas dan tanggungjawab konstitusional yang sangat penting, sebagaimana diyakini oleh Soekarno, bahwa nasionalisme tanpa keadilan sosial menjadi nihilisme. ${ }^{47}$ Nilai yang terkandung dalam sila keadilan sosial bagi seluruh rakyat Indonesia didasari oleh sila ketuhanan yang Maha Esa, Kemanusiaan yang adil dan beradab, persatuan Indonesia, serta kerakyatan yang dipimpin oleh hikmah kebijaksanaan dalam permusyawaratan perwakilan, dalam sila kelima terkandung nilai-nilai yang merupakan tujuan Negara sebagai tujuan dalam hidup bersama atau

44 Mubyarto, Sistem dan Moral Ekonomi Indonesia, Jakarta: LP3ES, 1990, hlm 23.

45 Mubyarto, Membangun Sistem Ekonomi, Yogyakarta:

BPFE-UGM, 2000, hlm. 42.

46Mubyarto, Ekonomi Pancasila, Yogyakarta: BPFEUGM, 2002, hlm. 39.

47Cindy Adams, Bung Karno Penyambung Lidah Rakyat, terjemahan oleh Abdul Bar Salim dari Soekarno, An Autobiography As Told To Cindy Adams, The Bobbs-Merrill Company Inc., New York, 1965, Jakarta: Gunung Agung, hlm.104. 
keadilan yang harus terwujud dalam kehidupan bersama (kehidupan sosial). Keadilan tersebut juga didasari dalam hubungan manusia dengan diri sendiri, hubungan manusia dengan manusia lain, masyarakat, bangsa negaranya dan manusia dengan Tuhannya. ${ }^{48}$

Pandangan bangsa Indonesia, untuk mewujudkan keadilan sosial tidak hanya sebatas bagi seluruh rakyat Indonesia, tetapi juga meliputi keadilan sosial bagi masyarakat dunia sebagai salah satu dasar dari upaya ikut melaksanakan ketertiban dunia. Pemahaman nasionalisme, yang menurut Soekarno, tidak dapat hidup subur kalau tidak dalam taman sarinya internasionalisme, keduanya bergandengan erat satu sama lain. ${ }^{49}$

Dasar filosofis sistem ekonomi Indonesia adalah Pancasila dan dasar konstitusionilnya adalah UUD 1945, tepatnya pada Pasal 23, Pasal 27, Pasal 33, dan Pasal 34 UUD 1945. Sistem ekonomi Indonesia adalah sistem ekonomi yang berorientasi kepada Ketuhanan Yang Maha Esa yaitu berlakunya etik dan moral agama, bukan materialisme; Kemanusiaan yang adil dan beradab yaitu tidak mengenal pemerasan atau eksploitasi; Persatuan Indonesia yaitu berlakunya kebersamaan, asas kekeluargaan, sosio nasionalisme dan sosio-demokrasi dalam ekonomi; Kerakyatan dengan mengutamakan kehidupan ekonomi rakyat dan hajat hidup orang banyak; serta Keadilan Sosial yang menjunjung tinggi persamaan, kemakmuran masyarakat yang utama bukan kemakmuran orangseorang. ${ }^{50}$

De mokrasi ekonomi merupakan konsep yang digagas oleh para pendiri Negara Indonesia (founding fathers) untuk menemukan sebuah bentuk perekonomian yang tepat dan sesuai dengan karakter bangsa Indonesia. Demokrasi ekonomi terkait erat dengan pengertian kedaulatan rakyat di bidang ekonomi. Istilah kedaulatan rakyat itu sendiri biasa dikembangkan oleh para ilmuwan sebagai konsep filsafat hukum dan filsafat politik. Kedaulatan rakyat itu lebih sering digunakan dalam studi ilmu hukum

\footnotetext{
48Kaelan, M.S, Pendidikan Kewarganegaraan, Yogyakarta: Paradigma, 2010, hlm .31-36

49Panitia Pemburu Jiwa Revolusi, Jakarta: Pantjawarsa Manipol, 1964, hlm. 310

50Sri Edi Swasono, Sistem Ekonomi dan Demokrasi Ekonom, Jakarta: UI Press, 1985, hlm.125-126.
}

daripada istilah demokrasi yang biasa dipakai dalam ilmu politik. Pengertian teknis keduanya sama saja, yaitu sama-sama berkaitan dengan prinsip kekuasaan yang berasal dari rakyat, oleh rakyat, dan untuk rakyat, sejalan dengan logika berpikir bahwa yang dapat dikuasai itu mencakup orang sebagai objek/subjek politik dan benda sebagai objek/subjek ekonomi, maka kekuasaan tertinggi yang berada di tangan rakyat dalam pengertian kita tentang konsep demokrasi juga meliputi cakupan yang sama, yaitu kedaulatan rakyat di bidang politik dan ekonomi.

Kedaulatan rakyat di bidang politik itulah yang selama ini dari tradisi liberalisme barat modern disebut dengan perkataan demokrasi. Istilah demokrasi ekonomi di dunia barat baru dikenal di kemudian hari setelah wacana tentang kedaulatan rakyat di bidang ekonomi mencapai perkembangan puncaknya dalam tradisi politik Eropa Timur yang akrab dengan paham sosialisme ekstrim. Gagasan kedaulatan rakyat di bidang ekonomi itu terkandung pengertian bahwa ide kekuasaan tertinggi yang berada di tangan rakyat mencakup tidak saja dalam lapangan politik, tetapi juga perekonomian. Sumber-sumber produksi pada pokoknya juga berada dalam penguasaan rakyat yang berdaulat. ${ }^{51}$

Istilah kesejahteraan sosial pertama kali digunakan oleh Soekarno, saat menyampaikan pidato rapat BPUPKI, tanggal 1 Juni 1945 yang membahas mengenai dasar Negara. Soekarno mengusulkan Pancasila sebagai dasar negara dengan salah satu dasar, yakni Kesejahteraan Sosial. Menurut Soekarno, dimaksudkan agar negara memberikan jaminan kesejahteraan dan pemerataan kepada seluruh rakyat. Sidang PPKI tanggal 18 Agustus 1945 disahkan UUD 1945, Bab tentang Kesejahteraan Sosial di ubah dengan nama Kesejahteraan Sosial dengan menghilangkan kata tentang, selain itu nomor babnya juga berubah menjadi Bab XIV setelah panitia memasukkan usulan agar Undang-Undang Dasar memuat bab mengenai pendidikan, begitu pula dengan pasalnya berubah menjadi Pasal 33 dan Pasal 34.

Menurut Soekarno, demokrasi yang harus dianut oleh Indonesia adalah demokrasi politik sekaligus demokrasi ekonomi, yang disebutnya

51 Jimly Asshiddiqie, Demokrasi Ekonomi,http://www.jimly.com diakses tanggal 20 Mei 2016, Jam: 14.50 WIB. 
demokrasi sosial, yang disebutnya "Socio Demokrasi". Soekarno menjelaskan bahwa demokrasi politik saja belum mencukupi. Demokrasi politik masih perlu dikomplitkan (dilengkapi) lagi dengan demokrasi ekonomi. ${ }^{52}$

Moh. Hata menjelaskan atas konsep demokrasi ekonomi, sebagai berikut:

"Perekonomian Indonesia Merdeka diatur dengan usaha bersama, dengan ini tidak dimaksud akan mematikan perusahaan yang kecil-kecil yang hanya dapat dikerjakan oleh orang seorang saja dan tiada menyinggung keperluan umum. Usaha bersama dilakukan terhadap kepada penghasilan yang besar-besar yang mengenai keperluan umum dan kemakmuran rakyat semuanya. Desentralisasi ekonomi dilakukan dengan memakai kooperasi sebagai dasar perekonomian." ${ }^{53}$

Pada masa pemerintahan Soeharto kekuasaan atas sumber kekayaan alam diwujudkan dalam bentuk pendirian badan usaha milik negara berlandaskan prinsip-prinsip kebersamaan dan kekeluargaan atau koperasi, dengan tetap mengacu kepada ideologi Pancasila. Munculnya gejolak politik yang dilatarbelakangi gejala ekonomi dan moneter di era reformasi akhirnya dilakukan perubahan atas UUD 1945. Ketentuan yang mengatur tentang Kesejahteraan Sosial, menjadi Bab tentang Perekonomian Nasional dan Kesejahteraan Sosial. Jumlah ayat dalam Pasal 33 bertambah yang semula tiga menjadi lima ayat, begitu pula Pasal 34, yang semula tanpa ayat menjadi empat ayat. ${ }^{54}$

Demokrasi ekonomi Indonesia tertuang dalam Pasal 33 ayat (2) dan ayat (3) UUD 1945 yang berbunyi:

"Cabang-cabang produksi yang penting bagi negara dan menguasai hajat hidup orang banyak dikuasai oleh negara. Bumi, air, dan kekayaan

52Soekarno, Di Bawah Bendera Revolusi, Jakarta: Panitia Penerbit Di Bawah Bendera Revolusi, 1964, hlm. 579-580.

53Sebagaimana dikutip Bagir Manan, "Memahami Pasal 33 UUD NRI 1945 Secara Historis," dalam Bagir Manan, Pertumbuhan dan Perkembanagn Konstitusi Suatu Negara, Bandung: Mandar Maju, 1995, hlm. 63-65.

54Mahkamah Konstitusi RI, 2010, Naskah Komprehensif Perubahan UUD Negara Republik Indonesia Tahun 1945. Latar Belakang, Proses, dan Hasil Perubahan 1999-2002.Buku ke VII Keuangan, Perekonomian Nasional, dan Kesejahteraan Sosial. Jakarta: Sekretariat Jenderal dan Kepaniteraan Mahkamah Konstitusi, hlm. 34-36. alam yang terkandung di dalamnya dikuasai oleh negara dan dipergunakan sebesar-besarnya untuk kemakmuran rakyat."

Pada sistem perbankan Indonesia, secara jelas asas demokrasi ekonomi disebutkan dalam Pasal 2 Undang-Undang Perbankan, yang menyebutkan Perbankan Indonesia dalam melakukan usahanya berasaskan demokrasi ekonomi dengan menggunakan prinsip kehati-hatian. Asas Demokrasi Ekonomi, ini berarti fungsi dan usaha perbankan diarahkan untuk melaksanakan prinsip-prinsip yang terkandung dalam demokrasi ekonomi yang berdasarkan Pancasila dan UUD 1945.

Asas kehati-hatian adalah suatu asas yang menyatakan bahwa bank dalam menjalankan fungsi dan kegiatan usahanya wajib menerapkan prinsip kehatihatian dalam rangka melindungi dana masyarakat yang dipercayakan padanya dengan demikian perbankan Indonesia dalam melakukan usahanya berasaskan demokrasi ekonomi dengan menggunakan prinsip kehati-hatian, hal ini bertujuan agar bank selalu dalam keadaan sehat sehingga masyarakat tetap menaruh kepercayaan pada dunia perbankan.

Penjelasan Umum Undang-Undang Nomor 10 Tahun 1998 Tentang Perubahan Atas UndangUndang Nomor 7 Tahun 1992 Tentang Perbankan menjelaskan bahwa posisi perbankan adalah sebagai lembaga intermediasi dan sebagai agen pembangunan. Penjelasan Atas UndangUndang Republik Indonesia Nomor 24 Tahun 2004 Tentang Lembaga Penjamin Simpanan juga disebutkan bahwa industri perbankan merupakan salah satu komponen sangat penting dalam perekonomian nasional demi menjaga keseimbangan kemajuan dan kesatuan eknonomi nasional. Stabilitas industri perbankan dimaksud sangat mempengaruhi stabilitas perekonomian secara keseluruhan, sebagaimana pengalaman yang pernah terjadi pada saat krisis moneter dan perbankan di Indonesia pada tahun 1998.

Kepercayaan masyarakat terhadap industri perbankan nasional merupakan salah satu kunci untuk memelihara stabilitas industri perbankan sehingga krisis tersebut tidak terulang. Kepercayaan ini dapat diperoleh dengan 
adanya kepastian hukum dalam pengaturan dan pengawasan bank serta penjaminan simpanan nasabah bank untuk meningkatkan kelangsungan usaha bank secara sehat. Kelangsungan usaha bank secara sehat dapat menjamin keamanan simpanan para nasabahnya serta meningkatkan peran bank sebagai penyedia dana pembangunan dan pelayan jasa perbankan.

Nuansa keadilan sosial dalam penyelenggaraan sistem perbankan di Indonesia dapat dilihat dari adanya asas demokrasi ekonomi yang berdasarkan Pancasila dan UUD 1945, dalam demokrasi ekonomi yang berdasarkan Pancasila dan UUD 1945 tersebut harus dihindarkan hal-hal sebagai berikut:

- Sistem Free Fight Liberalism Sistem yaitu sistem kebebasan usaha yang tidak terkendali, sistem ini dianggap tidak cocok dengan kebudayaan Indonesia dan berlawanan dengan semangat gotongroyong yang tercantum dalam Pasal 33UUD 1945, dan dapat mengakibatkan semakin besarnya jurang pemisah antara yang kaya dengan yang miskin yang menumbuhkan ekspolitasi terhadap manusia dan bangsa lain yang dalam sejarahnya di Indonesia telah menimbulkan dan mempertahankan kelemahan struktur ekonomi nasional dan posisi Indonesia dalam perekonomian dunia.

- Sistem Etatisme dalam arti bahwa: Negara beserta aparatur Negara bersifat dominan, mendesak dan mematikan potensi serta daya kreasi unit-unit ekonomi di luar sektor Negara.

Persaingan tidak sehat serta pemusatan kekuatan ekonomi pada satu kelompok dalam berbagai bentuk monopoli yaitu suatu bentuk pemusatan ekonomi pada satu kelompok tertentu, sehingga tidak memberikan pilihan lain kepada konsumen dan monopsoni yaitu keadaan dimana satu pelaku usaha menguasai penerimaan pasokan atau menjadi pembeli tunggal atas barang dan/atau jasa dalam suatu pasar komoditas yang merugikan masyarakat dan bertentangan dengan cita-cita keadilan sosial. ${ }^{55}$

Implementasi keadilan dalam penyelenggaraan 55 Zulfi Diane Zaini, Independensi Bank Indonesia ...Op.Cit, hlm. 55. Lihat juga: Zulfi Diane Zaini \& Syopian Febriansyah, Op.Cit, hlm. 13 perbankan nasional diwujudkan dengan adanya penjaminan simpanan nasabah bank dengan hadirnya Lembaga Penjamin Simpanan (LPS), yang dibentuk dengan Undang-Undang Nomor 24 Tahun 2004 tentang Lembaga Penjamin Simpanan, yang kemudian telah diubah dengan UndangUndang Nomor 7 Tahun 2009 tentang Penetapan Peraturan Pemerintah Pengganti Undang-Undang Nomor 3 Tahun 2008 tentang Lembaga Penjamin Simpanan menjadi Undang-Undang. Penjaminan seluruh kewajiban bank (blanket guarantee) pada masa lalu berdasarkan Keputusan Presiden, berhasil mewujudkan kepercayaan masyarakat terhadap industri perbankan pada masa krisis moneter dan perbankan.

Penjaminan yang sangat luas juga membebani anggaran negara dan menimbulkan moral hazard pada pihak pengelola bank dan nasabah bank. Pengelola bank tidak terdorong untuk melakukan usaha bank secara prudent, sementara nasabah tidak memperhatikan atau mementingkan kondisi kesehatan bank dalam bertransaksi dengan bank. Penerapan penjaminan secara luas ini yang berdasarkan kepada Keputusan Presiden kurang dapat memberikan kekuatan hukum sehingga menimbulkan permasalahan dalam pelaksanaan penjaminan. Ketentuan undang-undang tersebut upaya perlindungan terhadap nasabah bank lebih diarahkan kepada simpanan nasabah kecil, dengan demikian secara khusus yang dijamin oleh Lembaga Penjamin Simpanan adalah nasabah kecil untuk memberikan jaminan dari pihak bankir yang tidak bertanggungjawab terhadap para nasabah kecil.

Keadilan sosial harus menjadi tugas dan tanggungjawab konsitusional pemerintah Negara Indonesia melalui keberpihakannya kepada masyarakat ekonomi lemah maka upaya mewujudkan lembaga perbankan yang mendukung kesejahteraan masyarakat merupakan bagian penting dan strategis untuk masa sekarang dan masa yang akan datang, untuk mencapai tujuan itu.

Paradigmahukum utiliranianisme, keadilan dilihat secara luas. Ukuran satu-satunya untuk mengukur sesuatu adil atau tidak adalah seberapa besar dampaknya 
bagi kesejahteraan manusia (human welfare), apa yang dianggap bermanfaat dan tidak bermanfaat, diukur dengan perspektif ekonomi. ${ }^{56}$ Prinsip utility tersebut dikemukakan oleh Jeremy Bentham dalam karya monumentalnya Introduction to the Principles of Morals and Legislation (1789). Jeremy Bentham mendefinisikannya sebagai sifat segala benda tersebut cenderung menghasilkan kesenangan, kebaikan atau kebahagiaan, atau untuk mencegah terjadinya kerusakan, penderitaan dan kejahatan, serta ketidakbahagiaan pada pihak yang kepentingannya dipertimbangkan.

Aliran utilitas menganggap bahwa pada prinsipnya tujuan hukum itu hanya untuk menciptakan kemanfaatan atau kebahagiaan masyarakat. Aliran utilitas memasukkan ajaran moral praktis yang menurut penganutnya bertujuan untuk memberikan kemanfaatan atau kebahagiaan yang sebesar-besarnya bagi sebanyak mungkin warga masyarakat. Jeremy Bentham berpendapat, bahwa negara dan hukum semata-mata ada hanya untuk manfaat sejati, yaitu kebahagiaan mayoritas rakyat. ${ }^{57}$

Jhon Rawls ${ }^{58}$ terkait dengan paradigma hukum utiliranianisme, menyatakan bahwa perhatian utama keadilan sosial adalah keadilan institusi atau apa yang disebutnya sebagai struktur dasar masyarakat. Jhon Rawls berpendapat bahwa keadilan adalah ketidakberpihakan dan melalui kontrak sosial, individu-individu masyarakat secara bersama-sama menghasilkan barangbarang sosial, bukan untuk konsumsi individual.

Prinsip keadilan yang digunakan untuk menyusun atau mengevaluasi pendistribusian hak dan kewajiban yang fundamental dalam masyarakat tersebut sebagai prinsip keadilan sebagai fairness. ${ }^{59}$ Keadilan adalah kebajikan utama dari hadirnya institusi-institusi sosial (social institutions), akan tetapi, kebajikan bagi seluruh masyarakat tidak dapat mengesampingkan atau menggugat rasa keadilan dari setiap orang yang telah

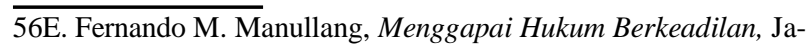
karta: Buku Kompas, 2007, hlm. 109.

57 Ahmad Ali, Menguak Tabir Hukum, Bogor: Ghalia Indonesia, 2008, hlm.204.

58 John Rawls, A Theory of Justice, (Revised Edition), Oxford University Press, 1999, hlm. 52.

59 John Rawls, A Theory of Justice, Massachusets: Harvard University, 1999, hlm.10.
}

memperoleh rasa keadilan, khususnya masyarakat lemah pencari keadilan. ${ }^{60}$

\section{Teori Hukum Pembangunan}

Mochtar Kusumaatmadja memperkenalkan teori Hukum Pembangunan. Terdapat 2 (dua) aspek yang melatarbelakangi kemunculan teori hukum ini, yaitu: Pertama, ada asumsi bahwa hukum tidak dapat berperan bahkan menghambat perubahan masyarakat. Kedua, dalam kenyataan di masyarakat Indonesia telah terjadi perubahan alam pemikiran masyarakat ke arah hukum modern. ${ }^{61}$

Mochtar Kusumaatmadja mengemukakan tujuan pokok hukum bila direduksi pada satu hal saja adalah ketertiban yang dijadikan syarat pokok bagi adanya masyarakat yang teratur. Tujuan lain hukum adalah tercapainya keadilan yang berbedabeda isi dan ukurannya, menurut masyarakat dan jamannya, ${ }^{62}$ untuk mencapai ketertiban diusahakan adanya kepastian hukum dalam pergaulan manusia di masyarakat, karena tidak mungkin manusia dapat mengembangkan bakat dan kemampuan yang diberikan Tuhan kepadanya secara optimal tanpa adanya kepastian hukum dan ketertiban. ${ }^{63}$

Fungsi hukum dalam masyarakat Indonesia yang sedang membangun tidak cukup untuk menjamin kepastian dan ketertiban. Menurut Mochtar Kusumaatmadja, hukum diharapkan agar berfungsi lebih daripada itu yakni sebagai "sarana pembaharuan masyarakat", "law as a tool of social engineering" atau "sarana pembangunan" dengan pokok-pokok pikiran sebagai berikut :64

"Mengatakan hukum merupakan "sarana pembaharuan masyarakat" didasarkan kepada anggapan bahwa adanya keteraturan atau ketertiban dalam usaha pembangunan dan pembaharuan itu merupakan suatu yang diinginkan atau dipandang 60 Pan Mohamad Faiz, Teori Keadilan John Rawls, dalam Jurnal Konstitusi, Volume 6 Nomor 1, 2009, hlm. 139140.

61Otje Salman dan Eddy Damian, (ed), Konsep-Konsep Hukum dalam Pembangunan dari Mochtar Kusumaatmadja, Bandung: Alumni, 2002, hlm. v.

62 Mochtar Kusumaatmadja, Fungsi dan Perkembangan Hukum dalam Pembangunan Nasional, Bandung: Bina Cipta, 1990, hlm. $2-3$.

63 Ibid, hlm. 13

64Mochtar Kusumaatmadja, Hukum, Masyarakat, dan Pembinaan Hukum Nasional, Bandung: Binacipta, 1995, hlm. 13. 
(mutlak) perlu, anggapan lain yang terkandung dalam konsepsi hukum sebagai sarana pembaharuan adalah bahwa hukum dalam arti kaidah atau peraturan hukum memang bisa berfungsi sebagai alat (pengatur) atau sarana pembangunan dalam arti penyalur arah kegiatan manusia ke arah yang dikehendaki oleh pembangunan dan pembaharuan."

Aksentuasi tolok ukur konteks di atas menunjukkan ada 2 (dua) dimensi sebagai inti Teori Hukum Pembangunan yang diciptakan oleh Mochtar Kusumaatmadja, yaitu: Pertama, ketertiban atau keteraturan dalam rangka pembaharuan atau pembangunan merupakan sesuatu yang diinginkan, bahkan dipandang mutlak adanya. Kedua, hukum dalam arti kaidah atau peraturan hukum memang dapat berfungsi sebagai alat pengatur atau sarana pembangunan dalam arti penyalur arah kegiatan manusia yang dikehendaki ke arah pembaharuan. Mochtar Kusumaatmadja juga berpendapat bahwa

Pengertian hukum sebagai sarana lebih luas dari hukum sebagai alat, karena: ${ }^{65}$

- Di Indonesia peranan perundang-undangan dalam proses pembaharuan hukum lebih menonjol, misalnya jika dibandingkan dengan Amerika Serikat yang menempatkan yurisprudensi (khususnya putusan the Supreme Court) pada tempat lebih penting.

- Konsep hukum sebagai "alat" akan mengakibatkan hasil yang tidak jauh berbeda dengan penerapan "legisme" sebagaimana pernah diadakan pada zaman Hindia Belanda, dan di Indonesia ada sikap yang menunjukkan kepekaan masyarakat untuk menolak penerapan konsep seperti itu.

- Apabila "hukum"di sini termasuk fuga hukum internasional, maka konsep hukum sebagai sarana pembaharuan masyarakat sudah diterapkan jauh sebelum konsep ini diterima secara resmi sebagai landasan kebijakan hukum nasional.

Teori hukum pembangunan memberikan dasar fungsi hukum sebagai "sarana pembaharuan masyarakat" (law as a tool social engineering) ${ }^{66} \mathrm{dan}$

65 Shidarta, Karakteristik Penalaran Hukum Dalam Konteks keIndonesian, Jakarta: Utomo, 2006, hlm.415.

66 Romli Atmasasmita, Menata Kembali Masa Depan-

Pembangunan Hukum Nasional, Makalah disampaikan hukum sebagai suatu sistem sangat diperlukan bagi bangsa Indonesia sebagai Negara yang sedang berkembang. ${ }^{67}$ Pada dasarnya, fungsi hukum sebagai "sarana pembaharuan masyarakat" (law as a tool of social engineering) relatif masih sesuai dengan pembangunan hukum nasional saat ini, namun perlu juga dilengkapi dengan pemberdayaan birokrasi (beureucratic engineering) yang mengedepankan konsep panutan atau kepemimpinan, sehingga fungsi hukum sebagai sarana pembaharuan dapat menciptakan harmonisasi antara elemen birokrasi dan masyarakat dalam satu wadah yang disebut "beureucraticand social engineering," ${ }^{68}$

Filosofi pembangunan nasional adalah pembangunan manusia Indonesia seutuhnya yang berdasarkan pada falsafah Negara Republik Indonesia. Asas pembangunan nasional terdiri dari:

- Asas Kemanfaatan,

- Asas Keadilan, dan

- Asas Kepastian.

Aspek kemanfaatan digambarkan oleh Roscue Pond sebagai berikut: "law as tool of social engineering”, yang artinya hukum dapat digunakan sebagai suatu sarana pembaharuan (untuk membentuk, membangun, merubah), hukum sebagai sarana rekayasa sosial. ${ }^{69}$

Kepastian hukum mengandung dua pengertian yaitu pertama, adanya aturan yang bersifat umum membuat individu mengetahui perbuatan apa yang boleh atau tidak boleh dilakukan, dan kedua, berupa keamanan hukum bagi individu dari kesewenangan pemerintah karena dengan adanya aturan yang bersifat umum itu individu dapat mengetahui apa saja yang boleh dibebankan atau dilakukan oleh Negara terhadap individu. ${ }^{70}$ Kepastian hukum sebagai asas hukum, dengan sendirinya menempatkan asas ini menjadi rujukan pertama baik dalam pengaturan perundangundangan maupun dalam berbagai aktivitas yang berhubungan dengan perlindungan nasabah oleh

dalam "Seminar Pembangunan Hukum Nasional VIII" di Denpasar, 14-18 Juli 2003, hlm. 7.

67 Lili Rasjidi dan Ida Bagus Wiyasa Putra, Hukum SebagaiSuatu Sistem, Bandung: Mandar Maju,2003, hlm. 5 et seq.

68Romli Atmasasmita, Menata Kembali...Op.Cit.,hlm. 7.

69 W. Friedman, Legal Theory, Dalam Naskah Akademis Tentang Peradilan Anak, Mahkamah Agung RI, Tahun, 2005, hlm.8.

70Riduan Syahrani, Rangkuman Intisari Ilmu Hukum, Bandung: Penerbit Citra Aditya Bakti, 1999, hlm.23. 
semua pihak yang terlibat di dalamnya. ${ }^{71}$

Gustav Radbruch menyebut keadilan, kemanfaatan, dan kepastian hukum sebagai "tiga ide dasar" atau "tiga nilai dasar hukum". ${ }^{72}$ Ketiga nilai dasar hukum tersebut oleh banyak ahli disebut sebagai tujuan hukum. Gustav Radbruch juga mengajarkan bahwa harus menggunakan asas prioritas di mana prioritas pertama selalu jatuh pada keadilan, baru kemanfaatan, dan terakhir kepastian hukum. ${ }^{73}$

Achmad Ali tidak menyetujui sepenuhnya pendapat Gustav Radbruch, sebagaimana dikatakannya:

"Penulis sendiri sependapat untuk menganut asas prioritas, tetapi tidak dengan telah menetapkan urutan prioritas seperti apa yang diajarkan Radbruch, yakni berturut-turut keadilan dulu baru kemudian kemanfaatan barulah terakhir kepastian hukum. Penulis sendiri menganggap hal yang lebih realistis jika kita menganut asas prioritas yang kausistis. Yang penulis maksudkan, ketiga tujuan hukum kita prioritaskan sesuai kasus yang kita hadapi, sehingga pada kasus A mungkin prioritasnya pada kemanfaatan, sedang untuk kasus B prioritasnya pada kepastian hukum.”

Melalui asas prioritas yang kausistis, dapat dikatakan tujuan hukum untuk mencapai keadilan, kemanfaatan, atau kepastian hukum semuanya tergantung pada kondisi riil atau kondisi faktual yang terjadi pada kasus tertentu. Menurut Maria Alfons bahwa upaya untuk mendapatkan perlindungan hukum tentunya yang diinginkan oleh manusia adalah ketertiban dan keteraturan antara nilai dasar dari hukum yakni adanya kepastian hukum, kegunaan hukum sertakeadilan hukum, meskipun pada umumnya dalam praktek ketiga nilai dasar tersebut bersitegang, namun haruslah diusahakan untuk ketiga nilai dasar tersebut bersamaan. ${ }^{74}$

Menurut Soedjono Dirdjosisworo dalam pergaulan

71Bandingkan dengan : Ahmadi Miru \& Sutarman Yodo, Hukum Perlindungan Konsumen, Jakarta: RajaGrafindo Persada, 2004, hlm.27.

72 Achmad Ali, Menguak Tabir Hukum, Jakarta: Chandra Pratama, 1996, hlm.95.

73 Ibid, hlm. 96

74 Maria Alfons, Implementasi Perlindungan Indikasi Geografis Atas Produk-produk Masyarakat Lokal Dalam Perspektif Hak Kekayaan Intelektual, Ringkasan Disertasi Doktor, Malang: Universitas Brawijaya, 2010, hlm.18. hidup manusia, kepentingan-kepentingan manusia bisa senantiasa bertentangan satu dengan yang lain, maka tujuan hukum adalah untuk melindungi kepentingankepentingan itu. ${ }^{75}$ Keseimbangan perlindungan antara pihak perbankan dan masyarakat menempatkan fungsi hukum yang menurut Roscoe Pound sebagai sarana pengendalian hidup bermasyarakat dengan menyeimbangkan kepentingan-kepentingan yang ada dalam masyarakat atau dengan kata lain sebagai sarana kontrol sosial. ${ }^{76}$ Keseimbangan perlindungan hukum ini tidak terlepas dari adanya regulasi yang mengatur tentang hubungan-hubungan hukum yang terjadi antara para pihak.

Hukum mempunyai tujuan dalam fungsinya sebagai perlindungan kepentingan manusia,. Hukum mempunyai sasaran yang hendak dicapai, adapun tujuan pokok hukum adalah mencapai tatanan masyarakat yang tertib menciptakan ketertiban dan keseimbangan. Terciptanya ketertiban di dalam masyarakat diharapkan kepentingan manusia akan terlindungi, dalam mencapai tujuannya itu hukum bertugas membagi hak dan kewajiban antar perorangan di dalam masyarakat, membagi wewenang dan mengatur cara memecahkan masalah hukum serta memelihara kepastian hukum. ${ }^{77}$

Menurut Sidharta salah satu fungsi hukum ${ }^{78}$ adalah memberikan perlindungan bagi kepentingan manusia. Satjipto Rahardjo juga menyatakan bahwa perlindungan hukum adalah memberikan pengayoman terhadap Hak Asasi Manusia (HAM) yang dirugikan orang lain, dan perlindungan itu diberikan kepada masyarakat agar dapat menikmati semua hak yang diberikan oleh hukum, ${ }^{79}$ secara konseptual, perlindungan hukum yang diberikan kepada rakyat Indonesia merupakan implementasi atas prinsip pengakuan dan perlindungan terhadap harkat dan martabat manusia. ${ }^{80}$

75 Soedjono Dirjosisworo, Pengantar Ilmu Hukum, Jakarta: Raja Grafindo Persada, 1983, hlm. 11.

76 Peter Mahmud Marzuki, Pembaharuan Hukum Ekonomi Indonesia, Surabaya: Universitas Airlangga, tanpa tahun, hlm.3.

77 Sudikno Mertokusumo, Mengenal Hukum (Suatu Pengantar), Yogyakarta: Liberty, 1999, hlm. 71.

78 Sidharta, Karakteristik Penalaran Hukum dalam Konteks KeIndonesiaan, Bandung: CV Utomo, 2006, hlm. 226-227.

79 Satjipto Rahardjo, Ilmu Hukum , Bandung: Citra Aditya Bakti, 2000, hlm 53.

80 Philipus M.Hadjon, Perlindungan Hukum bagi Rakyat Indonesia, Surabaya: PT. Bina Ilmu, 1987, hlm 2. 
Hukum dibutuhkan karena hukum tumbuh dan berkembang di dalam masyarakat, lebih lanjut dikatakan bahwa hukum harus fleksibel, fleksibilitas hukum dibutuhkan ketika harus menginterpretasikan hukum bukan atas apayang tertulis dalam undang-undang atau peraturan yang ada, melainkan juga harus mempertimbangkan nilai-nilai yang tumbuh dan berkembang dalam tatanan sosial. Pendasaran suatu tindakan atas dasar nilai-nilai tatanan sosial (etika) sangat berkaitan dengan hukum dan digunakan untuk memberikan arah bagi terciptanya keadilan. etika (moral) dan hukum memiliki hubungan seperti peta dan finalitas. ${ }^{81}$ Perlindungan hukum seharusnya juga bersifat prediktif, maka hukum yang dibuat tentunya akan beranjak dari pemahaman bidangbidang yang interdisipliner.

Pembangunan adalah suatu upaya untuk mentransformasikan masyarakat dari suatu kondisi ke kondisi yang lebih baik, oleh karena itu, proses transformasi harus diarahkan pada (1) penanggalan nilai-nilai lama yang tidak lagi relevan dengan kebutuhan, tantangan dan konteks zaman; (2) Modifikasi dan revitalisasi nilai-nilai lama yang masih relevan dengan kebutuhan, tantangan dan konteks zaman; (3) Penemuan dan pemasyarakatan nilai-nilai baru yang diperlukan untuk berinteraksi dengan lingkungan yang senantiasa berubah dan untuk menjawab permasalahan baru yang dibawa oleh perubahan Pembangunan adalah suatu upaya untuk mentransformasikan masyarakat dari suatu kondisi ke kondisi yang lebih baik, oleh karena itu, proses transformasi harus diarahkan pada (1) penanggalan nilai-nilai lama yang tidak lagi relevan dengan kebutuhan, tantangan dan konteks zaman; (2) Modifikasi dan revitalisasi nilai-nilai

lama yang masih relevan dengan kebutuhan, tantangan dan konteks zaman; (3) Penemuan dan pemasyarakatan nilai-nilai baru yang diperlukan untuk berinteraksi dengan lingkungan yang senantiasa berubah dan untuk menjawab permasalahan baru yang dibawa oleh perubahan. Pendapat ini dikemukakan oleh Wardiman

81 Ibid, hlm.96-98.
Djojonegoro, ketika menjadi pembicara kunci pada Kongres III ISKI di Yogyakarta. ${ }^{82}$ Hukum mempunyai makna yang lebih menyeluruh dan mendasar dibandingkan dengan istilah pembinaan hukum atau pembaharuan hukum. Pembinaan hukum lebih mengacu pada efisiensi, dalam arti meningkatkan efisiensi hukum. ${ }^{83}$ Pembaharuan hukum mengandung pengertian menyusun suatu tata hukum untuk menyesuaikan dengan perubahan masyarakat. Pembangunan hukum itu tidak hanya tertuju pada aturan atau substansi hukum, tetapi juga pada struktur atau kelembagaan hukum dan pada budaya hukum masyarakat. ${ }^{84}$

Proses pembangunan hukum berkaitan erat dengan (1) proses pembuatan hukum atau perangkat peraturan perundang-undangan yang memungkinkan nilai-nilai normatif yang hidup di dalam masyarakat untuk diformulasikan sedemikian rupa dankemudian dilegitimasikan oleh kekuasaan umum menjadi norma publik (law making process); (2) proses pelaksanaan dan penegakan (law enforcement) yang memungkinkan hukum yang dibangun dan dikembangkan menjadi hidup dan dapat bekerja secara fungsional (living law in action) dan; (3) proses pembinaan dan pembangunan kesadaran hukum masyarakat yang memungkinkan hukum dan sistem hukum yang dibangun memperoleh dukungan sosial dalam arti luas (legal awareness). ${ }^{85}$

Politik hukum di Indonesia mengarahkan pembangunan hukum dalam rangka meningkatkan daya saing bangsa, untuk mendukung terwujudnya pertumbuhan ekonomi yang berkelanjutan; mengatur permasalahan yang berkaitan dengan ekonomi, terutama dunia usaha dan dunia industri; serta menciptakan kepastian investasi, terutama penegakan dan perlindungan hukum. Pembangunan hukum juga diarahkan untuk menghilangkan kemungkinan terjadinya tindak pidana korupsi

\footnotetext{
82 Yahya M. Abdul Azis, ed., Visi Global Antisipasi Indonesia Memasuki Abad ke 21, Yogyakarta, Pustaka Pelajar, 1998.

83Satjipto Rahardjo, "Beberapa Pemikiran Tentang Ancangan Antar Disiplin dalam Pembinaan Hukum Nasional”, Jakarta: BPHN, 1993.hlm. 26

84 Satjipto Rahardjo, Hukum dan Perubahan Sosial, Bandung, Alumni, 1983. Bandingkan dengan pengertian Reformasi dari Satjipto Rahardjo dalam “Keluasan Reformasi Hukum”,Kompas, 8 Mei 1998.

85Jimly Asshiddiqie, Agenda Pembangunan Hukum Nasional Di Abad Globalisasi, Jakarta: PT Balai Pustaka, 1998, hlm.29-30.
} 
serta mampu menangani dan menyelesaikan secara tuntas permasalahan yang terkait Kolusi, Korupsi, Nepotisme (KKN). Pembangunan hukum dilaksanakan melalui pembaharuan materi hukum dengan tetap memperhatikan kemajemukan tatanan hukum yang berlaku dan pengaruh globalisasi sebagai upaya untuk meningkatkan kepastian dan perlindungan hukum, penegakan hukum dan hak-hak asasi manusia (HAM), kesadaran hukum, serta pelayanan hukum yang berintikan keadilan dan kebenaran, ketertiban dan kesejahteraan dalam rangka penyelenggaraan negara yang makin tertib, teratur, lancar, serta berdaya saing global. ${ }^{86}$

\section{Kesimpulan}

Sektor perbankan dalam kehidupan suatu negara merupakan agen pembangunan (agent of development), karena bank merupakan lembaga keuangan yang memiliki fungsi sebagai lembaga intermediasi keuangan (financial intermediary institution) yakni sebagai lembaga yang melakukan kegiatan penghimpunan dana dari masyarakat dalam bentuk simpanan dan menyalurkannya kembali kepada masyarakat dalam bentuk kredit atau pembiayaan. Perbankan juga merupakan agen kepercayaan (agent of trust) mengingat adanya salah satu prinsip pengelolaan bank yakni prinsip kepercayaan (fiduciary principle).

Ketentuan Pasal 4 Undang-Undang Nomor 7 Tahun 1992 tentang Perbankan sebagaimana telah diubah dengan Undang-Undang Nomor 10 tahun 1998 disebutkan bahwa perbankan Indonesia bertujuan menunjang pelaksanaan pembangunan nasional dalam rangka meningkatkan pemerataan, pertumbuhan ekonomi, dan stabilitas nasional kearah peningkatan kesejahteraan rakyat banyak. Pasal tersebut secara jelas mengamanatkan tugas bank sebagai agent of development.

Fungsi bank sebagai lembaga perantara keuangan yaitu lembaga yang menerima simpanan dari

masyarakat dan menyalurkannya kembali ke masyarakat, sangat penting bagi pertumbuhan

\footnotetext{
86Lampiran Undang-Undang Nomor 17 Tahun 2007 tentang Rencana Pembangunan Jangka Panjang Nasional Tahun 20052025, pada bagian Mewujudkan Bangsa yang Berdaya Saing huruf E No.34.
}

ekonomi suatu negara. Dana yang diterima dari masyarakat itu haruslah dikelola secara berhatihati sehingga pemilik dana (nasabah penyimpan) tidak khawatir tentang keamanan dan ketersediaan simpanannya bila dibutuhkan. ${ }^{87}$ Fungsi bank sebagai lembaga perantara dapat berjalan dibutuhkan adanya kepercayaan masyarakat. Pentingnya kepercayaan masyarakat bagi bank paling tidak karena dua alasan, pertama, meningkatkan efisiensi penggunaan bank dan efisiensi intermediasi, dan kedua, mencegah terjadinya bank runs and bank panics. ${ }^{88}$

\section{Saran}

Perlu keselarasan kebijakan serta peraturan perangkat hukum yang secara formal mengatur tegas dan jelas mengenai mekanisme koordinasi antar lembaga terkait dengan stabilitas sistem keuangan nasional dalam Sistem Perbankan. Sebagai bagian dari sistem keuangan perbankan diharapkan mampu meningkatkan perannya secara optimal sebagai lembaga intermediasi didalam momentum recovery setelah berlalunya krisis finansial. Diharapkan kontribusi perbankan yang lebih besar dalam menggerakkan perekonomian guna tercapainya kesejahteraan ekonomi dalam sistem perbankan Nasional, sesuai dengan Amanat UUD 1945.
87A Robert Abboud, Money in the Bank How Safe Is It, Homewood Bank Administration Institute, 1988, hlm.32.

88Zulkarnain Sitompul, Perlindungan Dana Nasabah Bank Suatu Gagasan tentang Pendirian Lembaga PenjaminSimpanan di Indonesia, Jakarta: Program Pascasarjana FH UI, 2002, hlm.2 


\section{Daftar Pustaka}

Ahmadi Miru \& Sutarman Yodo, Hukum Perlindungan Konsumen, Jakarta: RajaGrafindo Persada, 2004.

Achmad Ali, Menguak Tabir Hukum, Jakarta: Chandra Pratama, 1996.

Menguak Tabir Hukum, Bogor: Ghalia Indonesia, 2008.

Adriani Nurdin, Kepailitan BUMN Persero Berdasarkan Asas Kepastian Hukum, Jakarta: Alumni, 2012.

Astim Riyanto, Teori Konstitusi, Bandung: Yapemdo, 2000.

Abu Daud Busroh dan Abubakar Busro, Asaz-Asaz Hukum Tata Negara, Jakarta: Ghalia Indonesia, 1991.

Abdul Hakim G. Nusantara, 1988, Politik Hukum Indonesia, Jakarta: YLBHI, .

A Robert Abboud, Money in the Bank How Safe Is It, Homewood: Bank Administration Institute, 1988.

Bagir Manan, Menyongsong Fajar Otonomi Daerah, Yogyakarta: FH UII, 2001.

Politik Perundang-undangan Dalam Rangka Mengantisipasi Liberalisme Perekonomian, Bandar Lampung: FH-UNILA, 1996.

Pertumbuhan danPerkembanagn Konstitusi Suatu Negara, Bandung: Mandar Maju, 1995.

Cindy Adams, Bung Karno Penyambung Lidah Rakyat, terjemahan oleh Abdul Bar Salim dari Soekarno, An Autobiography As Told To Cindy Adams, The Bobbs-Merrill Company Inc., New York, 1965, Jakarta: Gunung Agung.

E. Suharto, Analisa Kebijakan Publik, Bandung: Alfabeta, 2006.

E. Fernando M. Manullang, Menggapai Hukum Berkeadilan, Jakarta: Buku Kompas, 2007.

Frans Magnis-Suseno, Etika Politik, Prinsip-prinsip Dasar Kenegaraan Modern, Jakarta: Gramedia Pustaka Utama, 1994.
Heri Herdiawanto \& Jumanta Hamdayama, Cerdas, Kritis, dan Aktif Berwarganegara, Jakarta: Erlangga, 2010.

Lili Rasjidi dan Ida Bagus Wiyasa Putra, Hukum Sebagai Suatu Sistem, Bandung: Mandar Maju,2003.

Julius R. Latumaerissa, Bank \& Lembaga Keuangan Lain Teori dan Kebijakan, Jakarta: Mitra Wacanaa Media, 2017.

Jimlly Asshiddiqie, Konstitusi dan Hak Asasi Manusia, Jakarta: disampaikan pada Lecture Peringatan 10 Tahun Kontras. 26 Maret 2008.

---------, Agenda Pembangunan Hukum Nasional Di Abad Globalisasi, Jakarta: PT Balai Pustaka, 1998.

, Hukum Tata Negara dan Pilar-Pilar Demokrasi, Jakarta: Konstitusi Press, 2005.

John Rawls, A Theory of Justice, (Revised Edition), Oxford University Press, 1999.

John Rawls, A Theory of Justice, Massachusets: Harvard University, 1999

Kaelan, M.S, Pendidikan Kewarganegaraan, Yogyakarta: Paradigma, 2010.

Marcus Lukman, Eksistensi Peraturan Kebijaksanaan dalam Bidang Perencanaan dan Pelaksanaan Rencana Pembangunan di Daerah Serta Dampaknya Terhadap Pembangunan Materi Hukum Tertulis Nasional, Disertasi, Bandung: Universitas Padjadjaran 1997.

Maria Alfons, Implementasi Perlindungan Indikasi Geografis Atas Produk-produk Masyarakat Lokal Dalam Perspektif Hak Kekayaan Intelektual, Ringkasan Disertasi Doktor, Malang: Universitas Brawijaya, 2010.

M. Yamin, Naskah Persiapan UUD 1945: Risalah Sidang BPUPKI/PPKI, Jakarta: Sekretariat Negara RI, 1959.

M. Mahfud MD, Politik Hukum di Indonesia, Jakarta: Rajawali Press, 2009.

Mustafa Luthfi dan J. Kurniawan, Perihal Negara, 
Hukum dan Kebijakan Publik : Perspektif Politik Kesejahteraan, Kearifan Lokal yang Pro Civil Society dan Gender, Malang: Setara Press, 2012.

Gagasan Kedaulatan Rakyat dalam Konstitusi dan Pelaksanaannya di Indonesia, Jakarta: Ichtiar Baru Van Hoeve, 1994

Mustafa Luthfi dan J. Kurniawan, Perihal Negara, Hukum dan Kebijakan Publik: Perspektif Politik Kesejahteraan, Kearifan Lokal yang Pro Civil Society dan Gender, Malang: Setara Press, 2012.

Muchsan, Sistem Pengawasan Terhadap Perbuatan Aparat Pemerintah dan Peradilan Tata Usaha Negara, Yogyakarta: Liberty, 2007.

Mubyarto, Pemberdayaan Ekonomi Rakyat dan Peranan Ilmu-Ilmu Sosial, Yogyakarta: BPFE, 2002.

\section{----------, Sistem dan Moral Ekonomi Indonesia,} Jakarta: LP3ES, 1990.

---------Membangun Sistem Ekonomi, Yogyakarta: BPFE-UGM.

---------Ekonomi Pancasila, Yogyakarta: BPFEUGM, 2002.

Mahkamah Konstitusi RI, 2010, Naskah Komprehensif Perubahan UUD Negara Republik Indonesia Tahun 1945. Latar Belakang, Proses, dan Hasil Perubahan 1999-2002.Buku ke VII Keuangan, Perekonomian Nasional, dan Kesejahteraan Sosial. Jakarta: Sekretariat Jenderal dan Kepaniteraan Mahkamah Konstitusi.

Mustafa Luthfi dan J. Kurniawan, Perihal Negara, Hukum dan Kebijakan Publik : Perspektif Politik Kesejahteraan, Kearifan Lokal yang Pro Civil Society dan Gender, Malang: Setara Press, 2012.

Mandala Manurung \& Prathama Rahardja, Uang, Perbankan, dan Ekonomi Moneter (Kajian Kontekstual Indonesia), Jakarta: FE-Universitas Indonesia, 2004.

Mochtar Kusumaatmaja, "Pengembangan Filsafat Hukum Nasional", dalam Pro Justitia Tahun XV Nomor 1 Januari 1997.

------------, Hukum, Masyarakat, dan Pembinaan Hukum Nasional, Bandung: Binacipta, 1995.
-, Fungsi dan Perkembangan Hukum dalam Pembangunan Nasional, Bandung: Bina Cipta, 1990.

Mohammad Jamin, Soehartono, Sri Lestari Rahayu \& Mulyanto, Politik Hukum Pengakuan Kesatuan Masyarakat Hukum Adat di Indonesia, Surakarta: UNS Press, 2015.

Peter Mahmud Marzuki, Pembaharuan Hukum Ekonomi Indonesia, Surabaya: Universitas Airlangga.

Philipus M.Hadjon, Perlindungan Hukum bagi Rakyat Indonesia, Surabaya: PT. Bina Ilmu, 1987.

Pan Mohamad Faiz, Teori Keadilan John Rawls, dalam Jurnal Konstitusi, Volume 6 Nomor 1, 2009.

Pokja Ideologi Lemhannas RI, Modul Bidang Studi/ Materi Pokok Pancasila dan Perkembangannya, PPRA XLVIII, TA. Lemhannas RI, 2012.

Panitia Pemburu Jiwa Revolusi, Jakarta: Pantjawarsa Manipol, 1964.

Ridwan HR, Hukum Administrasi Negara, Yogyakarta: UII Press, 2003.

Romli Atmasasmita, Menata Kembali Masa DepanPembangunan Hukum Nasional, Makalah disampaikan dalam "Seminar Pembangunan Hukum Nasional VIII" di Denpasar, 14-18 Juli 2003.

Riduan Syahrani, Rangkuman Intisari Ilmu Hukum, Bandung: Penerbit Citra Aditya Bakti, 1999.

Satjipto Rahardjo, Ilmu Hukum, Bandung: Citra Aditya Bakti, 2000.

-, "Beberapa Pemikiran Tentang Ancangan Antar Disiplin dalam Pembinaan Hukum Nasional", Jakarta: BPHN, 1993.

-, Hukum dan Perubahan Sosial, Bandung, Alumni, 1983..

Shidarta, Karakteristik Penalaran Hukum Dalam Konteks ke-Indonesian, Jakarta: Utomo, 2006.

S. Batunanggar, Indonesia's Banking Crisis 
Resolution: Lesson and the Way Forward, Oc- casional Internal Paper, Desember 2002.

Sudikno Mertokusumo, Mengenal Hukum (Suatu Pengantar), Yogyakarta: Liberty, 1999.

Solichin Abdul Wahab, Analisis Kebijaksanaan- dari Formulasi ke Implementasi Kebijaksanaan Negara, Jakarta: Bumi Aksara, 2008.

Sri Edi Swasono, Sistem Ekonomi dan Demokrasi Ekonom, Jakarta: UI Press, 1985.

Soekarno, Di Bawah Bendera Revolusi,Jakarta: Panitia Penerbit Di Bawah Bendera Revolusi, 1964.

Soedjono Dirjosisworo, Pengantar Ilmu Hukum, Jakarta: Raja Grafindo Persada, 1983.

W. Friedman, Legal Theory, Dalam Naskah Aka- demis Tentang Peradilan Anak, Mahkamah Agung RI, Tahun, 2005.

Yahya M. Abdul Azis, ed., Visi Global Antisipasi Indonesia Memasuki Abad ke 21, Yogyakarta, Pustaka Pelajar, 1998.

Zulkarnain Sitompul, Perlindungan Dana Nasa- bah Bank Suatu Gagasan tentang Pendirian Lembaga PenjaminSimpanan di Indonesia, Jakarta: Program Pascasarjana FH UI, 2002.

Zulfi Diane Zaini, Independensi Bank Indonesia dan Penyelesaian Bank Bermasalah, Bandung: Keni Media, 2012.

\section{Internet}

Jimly Asshiddiqie, Demokrasi Ekonomi,http://www. jimly.com diakses tanggal 20 Mei 2016, Jam: $14.50 \mathrm{WIB}$.

h t t p s: / / w w w . c n b c in d one s i a . c o m / market/20180709142737-17-22642/masalah-terbaru-perbankan-saat-ini-pengelolaan-likuiditas

http://www.lfip.org/english/pdf/bali-seminar/ Masalah\%20sistem\%20keuangan\%20dan\%20 perbankan\%20-\%20anwar\%20nasution.pdf 
Tô-râ: Volume 4 Nomor 2, Agustus 2018, Rospita A. Siregar, hal. 43-46

\section{Peraturan Perundan-Undangan}

Undang-Undang Republik Indonesia Nomor 10Tahun 1998 Tentang Perbankan

Lampiran Undang-Undang Nomor 17 Tahun 2007 tentang Rencana Pembangunan Jangka Panjang Nasional Tahun 2005-2025, pada bagian Mewu- judkan Bangsa yang Berdaya Saing huruf E No.34. 